\title{
Quality of life after minimally invasive surgery for rectal cancer
}

\author{
Jason H. Chen ${ }^{1}$, Jennifer M. Ayscue ${ }^{1}$, Mohammed Bayasi², James F. Fitzgerald ${ }^{1}$, Thomas J. Stahl' \\ Brian L. Bello ${ }^{1,2}$ \\ ${ }^{1}$ Colorectal Surgery Program at MedStar Washington Hospital Center, Washington, DC 20010, USA. \\ 2Department of Surgery, MedStar Georgetown University Hospital, Washington, DC 20010, USA.
}

Correspondence to: Dr. Brian L. Bello, Colorectal Surgery Program at MedStar Washington Hospital Center, 106 Irving St NW, Suite 2100 North, Washington, DC 20010, USA. E-mail: brian.I.bello@medstar.net

How to cite this article: Chen JH, Ayscue JM, Bayasi M, Fitzgerald JF, Stahl TJ, Bello BL. Quality of life after minimally invasive surgery for rectal cancer. Mini-invasive Surg 2018;2:42. http://dx.doi.org/10.20517/2574-1225.2018.59

Received: 28 Aug 2018 First Decision: 17 Oct 2018 Revised: 30 Oct 2018 Accepted: 30 Oct 2018 Published: 30 Nov 2018

Science Editor: Gordon N. Buchanan Copy Editor: Cui Yu Production Editor: Huan-Liang Wu

\begin{abstract}
Traditional open surgical technique for rectal cancer is associated with significant morbidity and impact on quality of life. Multiple structures are at risk during total mesorectal excision, which may have profound impact on sexual function, and urinary and fecal continence. In addition, having a temporary or permanent ostomy can have a significant effect on overall well-being. Patients have reported post-operative problems such as chronic wounds, poor body image, inhibited work and social function. Minimally invasive surgery (MIS) is an evolving component of colon and rectal cancer treatment that may have benefits over open surgery. The increasing role of laparoscopy for colon and rectal cancer has been associated with decreased morbidity, improved pain control, and reduced length of stay. However, laparoscopic surgery in rectal cancer remains technically difficult due to the inherent limitations of operating in the pelvis. Robotic surgery is a newer method for treating rectal cancer developed to overcome these limitations. Transanal endoscopic microsurgery and transanal MIS are techniques to achieve local excision, avoiding proctectomy in select patients, potentially improving functional outcomes. Transanal total mesorectal excision is an even newer technique to facilitate dissection of low rectal cancers. Controversy remains about equivalence in oncologic outcomes when these MIS approaches are used for rectal cancer. Even more unclear is the effect of MIS approaches on quality of life and how they compare to open surgery. This review discusses the most current evidence on the impact of various MIS techniques on quality of life after rectal cancer surgery.
\end{abstract}

Keywords: Quality of life, rectal cancer, minimally invasive surgery, laparoscopic, robotic, transanal endoscopic microsurgery, transanal minimally invasive surgery, transanal total mesorectal excision

\footnotetext{
(@) (

(C) The Author(s) 2018. Open Access This article is licensed under a Creative Commons Attribution 4.0 International License (https://creativecommons.org/licenses/by/4.0/), which permits unrestricted use, sharing, adaptation, distribution and reproduction in any medium or format, for any purpose, even commercially, as long as you give appropriate credit to the original author(s) and the source, provide a link to the Creative Commons license, and indicate if changes were made.
}

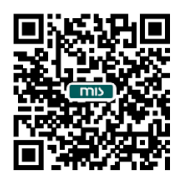




\section{INTRODUCTION}

The introduction of laparoscopy in the 1990s revolutionized the practice of surgery ${ }^{[1]}$. Minimally invasive surgery (MIS) forever changed a breadth of specialties including not only gynecology, urology, and general surgery, but also colorectal surgery ${ }^{[2]}$. The benefits of MIS are innumerable, including a reduction in pain and narcotic use, shorter length of stay, and earlier return to work compared to conventional open surgery $^{[2,3]}$. These tremendous improvements in functional outcomes have translated into an improved quality of life. Given the significant reduction in overall complications and costs, MIS has become the standard of care for multiple benign disease processes ${ }^{[2]}$.

In the setting of malignant disease, MIS must achieve equivalent oncologic outcomes in survival and local control compared to open surgery. The colon cancer laparoscopic or open resection (COLOR) trial and the United Kingdom Medical Research Council (MRC) conventional vs. laparoscopic-assisted surgery in colorectal cancer (CLASICC trial) demonstrated laparoscopic surgery for colon cancer to be as effective as open surgery in terms of oncologic outcomes and preservation of quality of life ${ }^{[1,4]}$. Since then, other multicenter prospective controlled studies have further supported the use of laparoscopic surgery as a safe and effective alternative to open surgery in the treatment of colon cancer, with five to ten year follow-up analyses showing equal if not better oncologic and functional outcomes ${ }^{[4,5]}$.

Despite the strong evidence for the treatment of colon cancer, the evidence in support of MIS as a standard for rectal cancer is not clear. Furthermore, the definition of MIS for rectal cancer is broad and continues to evolve with the incorporation of multiple platforms for treatment including robotic-assisted approaches, transanal endoscopic microsurgery (TEM), transanal minimally invasive surgery (TAMIS), and transanal total mesorectal excision (TaTME). Given the unique anatomic location of rectal cancers deep in the pelvis, the pelvic blood vessels, autonomic nerves, and anal sphincters are all at high risk for injury during surgery. Open surgery is associated with significant rates of postoperative sexual and urinary dysfunction ranging from $20 \%$ to $100 \%$ leading to a profound effect on overall well-being ${ }^{[6,7]}$.

There has been more emphasis on measuring "quality of life" after oncologic resection in recent years. This perhaps is rooted in the The World Health Organization's definition of health as "a state of complete physical, mental, and social well-being and not merely the absence of disease." Quality of life may depend on many variables including patient factors (e.g., age, culture), tumor factors (e.g., size, distance from anal verge) and treatment factors (e.g., need for ostomy, radiation, type of surgery).

Early studies on minimally invasive approaches for rectal cancer have not all shown equivalent oncologic outcomes, and it is still unclear what the effect of these approaches is on functional outcomes. Clinicians need to counsel patients on the potentially profound effects on quality of life with any approach. In this review, we examine the evidence on the quality of life outcomes of MIS in treating rectal cancer.

\section{SEARCH STRATEGY}

The PubMed database was queried for keywords "rectal cancer", "quality of life", "functional outcomes", "minimally invasive surgery", "laparoscopic", "robotic", "transanal endoscopic microsurgery", "transanal minimally invasive surgery", and "transanal total mesorectal excision". Clinical trials, review articles, and meta-analyses in English that measured patients' quality of life after rectal cancer were included for review. Studies were excluded if patients were not distinguished between colon and rectal cancer in the study.

\section{QUALITY OF LIFE ASSESSMENT}

The assessment of quality of life depends on patient-reported outcomes conducted through questionnaires. The most common questionnaires include the non cancer-specific instrument, the medical outcomes study 
short form general health survey of 36 questions (SF-36); a cancer-specific instrument, the European organization for research and treatment of cancer quality of life questionnaire EORTC QLQ-C30 version 3.0; and the two colorectal cancer-specific instruments, the EORTC colorectal quality of life questionnaire QLQ-CR38 and QLQ-CR29 ${ }^{[8-12]}$. The SF-36 questionnaire is a generic health survey that can be applied across different diseases and treatment groups. It seeks to capture the physical, mental, and social health of patients through 36 questions. The EORTC quality of life questionnaires were developed by a broad range of professionals involved in the care of cancer to provide a multidimensional assessment of health for the cancer patient that could be self-administered and applicable across a range of cultural settings. The QLQC30 questionnaire consists of 30 items divided into functional scales of physical, emotional, cognitive, and social function; a symptom scale, and a global health scale. The symptom scales include assessments on pain, fatigue, appetite, insomnia, and emesis. The EORTC QLQ-CR38 and QLQ-CR29 colorectal cancer specific questionnaire addresses issues specific to colorectal cancer patients related to gender, urinary and fecal incontinence, and problems associated with having a stoma.

The International Prostatic Symptom Score (IPSS) questionnaire measures urinary incontinence and the International Index of Erectile Function (IIEF) questionnaire measures male sexual dysfunction. IPSS evaluates urinary issues such as frequency, urgency, nocturia, dysuria, and straining during micturition. The international consultation on incontinence male/female lower urinary tract symptoms were also used in some studies ${ }^{[13-16]}$. The IIEF-5 assesses various aspects of male sexual function including erection, penetration, ejaculation, desire, and overall enjoyment ${ }^{[17]}$. The female sexual function index (FSFI) questionnaire assesses female sexual function, exploring aspects of sexuality including desire, arousal, lubrication, satisfaction, pain, and confidence ${ }^{[18]}$.

\section{LAPAROSCOPIC SURGERY FOR RECTAL CANCER}

Laparoscopic surgery is now more utilized than open surgery for colon cancer due to favorable shortterm outcomes related to smaller incisions, including less pain, reduced blood loss, and improved recovery time $^{[19]}$. Furthermore, the use of the laparoscope allows for the projection of a high resolution, magnified, well-illuminated image of the operative field on multiple monitors. The ten-year outcomes of the COLOR trial demonstrated equivalent oncologic outcomes between laparoscopic and open surgery for colon cancer in terms of overall survival, disease-free survival, and local recurrence ${ }^{[20]}$. The purported advantage of laparoscopic surgery in rectal cancer is better visualization of the deep pelvis and possibly a more accurate dissection for a total mesorectal excision (TME) than in open surgery. However, laparoscopy in the pelvis is technically difficult, especially in obese patients with low tumors or narrow pelvises. Maintenance of a stable camera view and adequate retraction is not often ergonomic, leading to a loss of exposure from surgeon and assistant fatigue.

Multiple single center studies have reported quality of life outcomes after laparoscopic surgery for rectal cancer. In 2006, a single center prospective longitudinal study conducted in the Netherlands examined the quality of life and sexual function of 51 patients with rectal cancer who underwent either a laparoscopic low anterior resection $(n=38,75 \%)$ or laparoscopic abdominoperineal resection $(n=13,25 \%)^{[20]}$. These patients were surveyed with three quality of life questionnaires: SF-36, EORTC QLQ-C30, and EORTC QLQ-CR38. The questionnaires were given preoperatively, and postoperatively upon discharge, and at 3, 6, and 12 months. The study found that although physical function, social function, vitality, and pain scores were all worse at the time of discharge compared to baseline scores, all of these measures improved to baseline by three months and were maintained up to one year postoperatively. Improved mental function compared to baseline was noted at three months and emotional function improvement was also noted at one year. Patients also reported an improvement in global quality of life at one year after surgery compared to their baseline preoperative level. This improvement included alleviation of symptoms of fatigue, pain, appetite loss, and diarrhea. There was no comparison group to open in this study ${ }^{[20]}$. 
Braga et al..$^{[21]}$ in 2007 conducted a single center randomized control trial in Italy comparing 168 patients (83 laparoscopic vs. 85 open) for rectal cancer $<15 \mathrm{~cm}$ from anal verge and demonstrated improved general health, physical functioning and social functioning in the laparoscopic group at 3, 6, and 12 months after surgery. In a single center prospective cohort study in India examining sexual and urinary dysfunction in male patients after laparoscopic TME, 34 patients with low (0-6 cm from anal verge) to mid (7-12 cm from anal verge) rectal cancers who underwent laparoscopic low anterior resections were given IPSS and IIEF questionnaires prior to surgery, and at $1,3,6$, and 12 months after surgery ${ }^{[22]}$. The study found patients to have moderate to severe bladder dysfunction in $29.4 \%$ of patients at one month which decreased to $2.9 \%$ at one year. Of the 17 men who were sexually active prior to surgery, $75 \%$ of them reported sexual dysfunction at one month after surgery, which improved with time to $42 \%$ of patients at one year after surgery. The sexual dysfunction reported at one year included impotence for $11 \%$ of patients, and issues of retrograde ejaculation and decreased climax for $31 \%$ patients ${ }^{[22]}$.

There have been multiple randomized trials examining laparoscopic $v s$. open surgery for rectal cancer. The MRC CLASICC trial was a multicenter randomized trial conducted in the UK between 1996 and 2002 in which 794 patients were randomized to either open $(n=268)$ or laparoscopic $(n=526)$ surgery for colon or rectal cancer ${ }^{[4,23]}$. Of these patients, 347 completed questionnaires up to three years post-operatively including the QLQ-C30, QLQ-CR38, IPSS, IIEF, and FSFI. The author found that global quality of life, role functioning, cognitive functioning, pain, and nausea/vomiting remained the same as baseline at 6 months and 3 years after surgery. Social function was worse in the laparoscopic group up to three years after surgery, but remained the same at baseline for the open group. Furthermore, there was no overall difference in bladder function after open $v s$. laparoscopic colorectal cancer surgery. Overall sexual function in men was worse at 3 months after laparoscopic surgery, but by 6 months there was no statistical difference. Additionally, the two independent risk factors for postoperative male dysfunction were TME and conversion to open surgery. Adjusting for neoadjuvant radiation therapy did not change the result as the proportion was similar in both groups. No differences in sexual function were found between laparoscopic $v$ s. open surgery for women ${ }^{[4,23]}$. However, a low response rate from women precluded any meaningful conclusions.

The comparison of open $v s$. laparoscopic surgery for mid-rectal or low-rectal cancer after neoadjuvant chemoradiotherapy (COREAN) trial in 2014 and colorectal cancer laparoscopic or open resection (COLOR II) trial in 2015 were both multicenter, non-inferiority, randomized controlled trials that concluded that laparoscopic surgery was non-inferior to open surgery for the treatment of rectal cancer in terms of threeyear disease free survival, overall survival, and local recurrence ${ }^{[24,25]}$. In the COREAN trial, the validated Korean version of the EORTC QLQ-CR38 questionnaire was given pre-operatively and at months 3, 12, 24, and 36 months after proctectomy. Clinical meaningful differences in quality of life were considered if a ten point difference in a mean score was identified. No clinically significant differences in quality of life were noted. Therefore, although the study concluded that laparoscopic resection for locally advanced rectal cancer after neoadjuvant chemoradiation was non-inferior to open resection in the context of oncologic outcomes, there was no significant benefit in functional outcomes with laparoscopic surgery compared to open surgery ${ }^{[24]}$. Quality of life data from the COLOR II trial also demonstrated no difference in sexual dysfunction and micturition symptoms after laparoscopic $v s$. open surgery for rectal cancer ${ }^{[25,26]}$.

While the COREAN and COLOR II trials both concluded in favor of laparoscopic surgery as a safe noninferior alternative to open surgery, the effect of laparoscopic-assisted resection $v s$. open resection of stage II or III rectal cancer on pathologic outcomes, the ACOSOG Z6051 trial in the U.S. and Australasian laparoscopic cancer of the rectum (ALaCaRT) trial in Australia both found that laparoscopic surgery failed to prove to be non-inferior to open surgery in regards to successful oncologic resections ${ }^{[27,28]}$. They concluded that the use of laparoscopic surgery for rectal cancer should be conducted with caution. Secondary outcomes including survival and local recurrence are still being collected. Quality of life outcomes will be reported in the future. 
A summary of studies examining quality of life after laparoscopic surgery for rectal cancer is found in Table 1.

\section{ROBOTIC SURGERY FOR RECTAL CANCER}

Robotic surgery was developed to overcome many of the challenges of laparoscopic surgery while maintaining a minimally invasive approach. The multi-arm robotic platform can provide constant retraction avoiding fatigue, while the steady, high-definition three-dimensional view and enhanced articulation of instruments may allow for a precise dissection. Proponents argue that the approach may decrease the rate of conversion to open surgery, while allowing a more complete TME to achieve a superior oncologic outcome without injury to the sphincters, or nerves involved in urinary and sexual function.

Early studies on robotic surgery for rectal cancer focused on safety and feasibility while more recent studies transitioned to studying oncologic outcomes followed by quality of life measurements. Multiple single center comparison studies have been done reporting both cancer specific outcomes and quality of life assessment. D'Annibale et al. ${ }^{[29]}$ in 2013 performed a retrospective study of 60 patients, 30 who underwent robotic TME and 30 who underwent laparoscopic TME, and found that both groups demonstrated significantly worse erectile function one month after surgery. However, erectile function was completely restored one year after surgery in the robotic group but only partially restored in the laparoscopic group. Bladder function was significantly worse at one month after surgery but normalized at one year in both groups ${ }^{[29]}$. Similarly, a prospective study by Kim et al. ${ }^{[30]}$ in 2012 found that out of 30 robotic TME and 39 laparoscopic TME patients, there was an earlier restoration of both bladder function and sexual function in the robotic group compared to the laparoscopic group. This was again demonstrated in another retrospective study of 29 men, 14 who underwent robotic intersphincteric resections, and 15 who underwent laparoscopic intersphincteric resections ${ }^{[31]}$. The authors found improvement in sexual function at 6 months post-operatively in the robotic group but no difference in bladder function or fecal incontinence ${ }^{[31]}$. An additional study of robotic vs. laparoscopic TME patients demonstrated significant improvement in sexual function in only the robotic group at 6 months ${ }^{[32]}$. A meta-analysis of these four studies found significant improvement in male sexual function, specifically erectile function at 3 and 6 months after robotic surgery ${ }^{[33]}$. Although there was a trend toward improved urinary function with robotic surgery compared to laparoscopic surgery, it was not statistically significant ${ }^{[33]}$.

Kamali et al. ${ }^{[34]}$ followed 36 consecutive patients, 18 who underwent a laparoscopic anterior resection and 18 who underwent a robotic anterior resection for a median of 12 months after surgery. The EORTC QLQCR30 and QLQ-CR29 questionnaires were used. The laparoscopic group reported better social function than the robotic group. The robotic group, however, reported lower pain scales and lower levels of insomnia than the laparoscopic group. Furthermore, there was higher male impotence scores in the laparoscopic group compared to the robotic group $(33 \pm 35 \text { vs. } 7 \pm 21, P=0.03)^{[34]}$. The authors attributed this positive finding to the enhanced vision, sharp targeted dissection, and limited thermal injury of robotic surgery.

Two larger single center studies have been done more recently. One was a quality of life study using a propensity score matched analysis, studying a total of 260 patients (130 robotic and 130 laparoscopic ${ }^{[35]}$. Patients were given questionnaires (EORTC QLQ-C30, IPSS, and IIEF-5) preoperatively and at 3, 6, and 12 months after surgery. A subgroup of 48 matched male pairs who were sexually active prior to surgery was analyzed. The matched groups showed no significant differences in quality of life scores prior to surgery. The laparoscopic group had significantly impaired role and social function 3 months after surgery, which the robotic surgery group did not exhibit. At 6 months after surgery, the robotic group had higher emotional function scores than the laparoscopic group. In examining symptom scores, the laparoscopic group showed worsening fatigue, insomnia, and financial difficulties at three months after surgery, which the robotic group did not. The robotic group also had significantly better urinary function (lower IPSS 
Table 1. Laparoscopic surgery for rectal cancer

\begin{tabular}{|c|c|c|c|c|c|c|c|c|}
\hline Ref. & Study type & Randomization & $\begin{array}{c}\text { Group } \\
\text { studied }\end{array}$ & Sample size & Follow up & Questionnaires & Main findings & $\begin{array}{l}\text { Level of } \\
\text { evidence }\end{array}$ \\
\hline $\begin{array}{l}\text { Breukink et al. }{ }^{[20]}, \\
2007\end{array}$ & $\begin{array}{l}\text { Prospective } \\
\text { single center }\end{array}$ & No & $\begin{array}{l}\text { Lap LAR } \\
\text { vs. Lap } \\
\text { APR }\end{array}$ & $\begin{array}{l}51 \text { (38 Lap } \\
\text { LAR, } 13 \text { Lap } \\
\text { APR) }\end{array}$ & 12 months & $\begin{array}{l}\text { SF-36, EORTC } \\
\text { QLQ-C30, QLQ- } \\
\text { CR38 }\end{array}$ & $\begin{array}{l}\text {-LAR had better sexual } \\
\text { function, body image, } \\
\text { and overall QOL } \\
\text { - LAR had less fatigue, } \\
\text { pain, appetite loss, } \\
\text { and diarrhea at } 12 \\
\text { months compared to } \\
\text { baseline }\end{array}$ & $2 b$ \\
\hline $\begin{array}{l}\text { Braga et al. }{ }^{[21]}, \\
2007\end{array}$ & $\begin{array}{l}\text { Prospective } \\
\text { single center }\end{array}$ & Yes $(1: 1)$ & $\begin{array}{l}\text { Lap vs. } \\
\text { Open } \\
\text { TME }\end{array}$ & $\begin{array}{l}168 \text { ( } 83 \text { Lap, } \\
85 \text { Open) }\end{array}$ & 12 months & SF-36 & $\begin{array}{l}\text {-Lap had better overall } \\
\mathrm{QOL} \text { at } 12 \text { months } \\
\text { compared to open }\end{array}$ & 1 \\
\hline $\begin{array}{l}\text { George et al. }{ }^{[22]}, \\
2018\end{array}$ & $\begin{array}{l}\text { Prospective } \\
\text { single center }\end{array}$ & No & $\begin{array}{l}\text { Lap } \\
\text { TME in } \\
\text { male } \\
\text { patients }\end{array}$ & 34 & 12 months & IPSS, IIEF & $\begin{array}{l}\text {-Urinary dysfunction } \\
\text { in } 20 \% \text { at } 3 \text { months to } \\
3 \% \text { at } 9 \text { months } \\
\text { - Sexual dysfunction } \\
\text { in } 75 \% \text { at } 3 \text { months to } \\
42 \% \text { at } 12 \text { months }\end{array}$ & $2 b$ \\
\hline $\begin{array}{l}\text { Jayne et al. }{ }^{[4,23]}, \\
2007 \text { (CLASICC) }\end{array}$ & $\begin{array}{l}\text { Prospective } \\
\text { multicenter }\end{array}$ & Yes (2:1) & $\begin{array}{l}\text { Lap vs. } \\
\text { Open } \\
\text { TME }\end{array}$ & $\begin{array}{l}347 \text { (526 Lap, } \\
268 \text { Open) }\end{array}$ & 36 months & $\begin{array}{l}\text { EORTC QLQ-C30, } \\
\text { QLQ-CR38 }\end{array}$ & $\begin{array}{l}\text {-Lap had worse sexual } \\
\text { function at } 3 \text { months } \\
\text { but no difference at } 6 \\
\text { months to } 36 \text { months } \\
\text { compared to open } \\
\text {-Lap had worse social } \\
\text { function at } 36 \text { months } \\
\text { compared to open }\end{array}$ & 1 \\
\hline $\begin{array}{l}\text { Jeong et al. }{ }^{[24]} \text { ' } \\
2014 \text { (COREAN) }\end{array}$ & $\begin{array}{l}\text { Prospective } \\
\text { multicenter }\end{array}$ & Yes $(1: 1)$ & $\begin{array}{l}\text { Lap } v s . \\
\text { Open } \\
\text { TME } \\
\text { mid to } \\
\text { low }\end{array}$ & $\begin{array}{l}340 \text { (170 Lap, } \\
170 \text { Open) }\end{array}$ & 36 months & $\begin{array}{l}\text { EORTC QLQ-C30, } \\
\text { QLQ-CR38 }\end{array}$ & $\begin{array}{l}\text {-No difference in over- } \\
\text { all QOL at } 36 \text { months }\end{array}$ & 1 \\
\hline $\begin{array}{l}\text { Andersson et al. }{ }^{[25,26]}, \\
2014 \text { (COLOR II) }\end{array}$ & $\begin{array}{l}\text { Prospective, } \\
\text { multicenter }\end{array}$ & Yes (2:1) & $\begin{array}{l}\text { Lap vs. } \\
\text { Open } \\
\text { TME }\end{array}$ & $\begin{array}{l}385 \text { (260 Lap, } \\
125 \text { Open) }\end{array}$ & 24 months & $\begin{array}{l}\text { EORTC QLQ- } \\
\text { CR38 }\end{array}$ & $\begin{array}{l}\text {-No difference in over- } \\
\text { all QOL at } 24 \text { months }\end{array}$ & 1 \\
\hline $\begin{array}{l}\text { Fleshman et } a l^{[27]}, \\
2015 \text { (ACOSOG } \\
\text { Z6051) }\end{array}$ & $\begin{array}{l}\text { Prospective } \\
\text { multicenter }\end{array}$ & Yes (1:1) & $\begin{array}{l}\text { Lap vs. } \\
\text { Open } \\
\text { TME }\end{array}$ & $\begin{array}{l}462 \text { (240 Lap, } \\
222 \text { Open) }\end{array}$ & & - & -Pending & 1 \\
\hline $\begin{array}{l}\text { Stevenson et al. }{ }^{[28]}, \\
2015 \text { (ALaCaRT) }\end{array}$ & $\begin{array}{l}\text { Prospective, } \\
\text { multicenter }\end{array}$ & Yes $(1: 1)$ & $\begin{array}{l}\text { Lap vs. } \\
\text { Open } \\
\text { TME }\end{array}$ & $\begin{array}{l}475 \text { (238 Lap, } \\
237 \text { Open) }\end{array}$ & - & - & -Pending & 1 \\
\hline
\end{tabular}

Lap: laparoscopic; TME: total mesorectal excision; LAR: low anterior resection; APR: abdominoperineal resection; QOL: quality of life; SF-36: short form general health survey of 36 questions; EORTC QLQ-C30: European organization for research and treatment of cancer quality of life questionnaire, 30 cancer non-specific questions; EORTC QLQ-CR38: European organization for research and treatment of cancer quality of life questionnaire, 38 colorectal cancer specific questions; IPSS: International Prostatic Symptom Score; IIEF: International Index of Erectile Function; Level of evidence: 1: randomized controlled trial; 2a: randomized prospective cohort study; 2b: nonrandomized prospective cohort study; 3: retrospective cohort study; 4: case series

scores) than the laparoscopic group at 6 months in males. Furthermore, the male patients in the robotic group demonstrated a return to baseline in urinary symptoms at 12 months that was not achieved in the laparoscopic group. There were no significant differences found in female patients between groups compared to baseline. Sexual function returned to baseline at 6 months in the robotic group, but did not return to baseline until 12 months after surgery in the laparoscopic group. Overall, this study showed that although quality of life worsens initially after surgery, the robotic group had an earlier return to baseline quality of life than the laparoscopic group ${ }^{[35]}$.

Another large single center study compared open $(n=114) v s$. robot-assisted $(n=108)$ intersphincteric resections and found that at 6 and 12 months post operatively, robotic-assisted surgeries resulted in improved fecal incontinence scores (12.5 and 7.7 in the robotic group, and 14.2 and 10.3 in the open group, $P<0.001)^{[36]}$. At 6 months post-operatively, severe sexual dysfunction occurred 2.7 times more in the open group than the robotic-assisted group $(34.1 \%$ vs. $12.5 \% ; P=0.023)$ in male patients over the age of 65 . Specifically, erectile dysfunction was more common in the open group than the robotic group $(31.8 \% \text { vs. } 12.5 \%, P=0.04)^{[36]}$. 
There is only one randomized study looking at quality of life between the robotic and laparoscopic approach. Jayne et al. ${ }^{[37]}$ conducted the effect of robotic $v s$. laparoscopic resection for rectal cancer (ROLARR) trial. In this international multicenter study, 471 patients were randomized between 2011 and 2014 to either robotic-assisted or laparoscopic rectal cancer surgery for either high (upper rectum) or low (total rectum) anterior resection or abdominoperineal resection (rectum and perineum). The study included 40 surgeons at 29 sites across 10 countries between 2011 to 2014. To be part of the study, surgeons were required to have performed 30 minimally-invasive rectal resections with at least 10 robotically and 10 laparoscopically. On average, patients received an operation performed by a surgeon with experience of a median 91 previous laparoscopic operations or a median 50 previous robotic-assisted operations. The primary outcome revealed a conversion to open rate of $8.1 \%$ for robotic-assisted and $12.2 \%$ for laparoscopic surgery with no statistical significant difference $(P=0.16)$. The two factors that did show a statistically significant odds ratio for conversion to open surgery were a high body mass index and male gender. Of the two quality of life measures compared, bladder dysfunction and sexual dysfunction, neither were statistically different. The IPSS scores for bladder function were similar at baseline between the two groups pre-operatively and at 6 months post-operatively. In examining male sexual dysfunction with IIEF scores and female sexual dysfunction with FSFI scores, no statistically significant differences were identified between groups comparing baseline scores to 6 months after surgery ${ }^{[37]}$.

A summary of studies examining quality of life after robotic surgery for rectal cancer is found in Table 2 .

\section{TEM}

TEM is a method by which select mid and proximal T1No rectal cancer and adenomas are excised endoscopically. A $40 \mathrm{~mm}$ diameter and up to $20 \mathrm{~cm}$ long rectoscope is inserted through the anus using a blunt obturator. Once the obturator is removed, a faceplate with ports is inserted. An insufflation system generates and maintains constant pneumorectum. The entire rigid platform is attached to the operating table. Proponents describe the technique as one allowing a local excision to be performed with a lower rate of positive margins, tumor fragmentation, and local recurrence compared to transanal excision ${ }^{[38]}$. Furthermore, the technique allows for the local resection of more proximal tumors than accessible through conventional transanal excision to be performed without a transabdominal complete mesorectal excision and rectal resection. This technique additionally negates the need for a diverting stoma. However, critics argue that the $40 \mathrm{~mm}$ diameter rectoscope may stretch the sphincter complex, impair anorectal function, and can cause fecal incontinence impairing quality of life. Furthermore, the cost of the instruments and platforms is greater than that of a TAMIS set up, but less than open surgery.

Allaix et al. ${ }^{[39]}$ was one of the first to assess TEM for effects on quality of life. They studied 93 patients who had undergone TEM for benign rectal lesions or T1No rectal cancer and found that the Wexner incontinence scale (range 0-10) was increased from baseline at 3 months, began to decline at 12 months and returned to baseline preoperative value at 60 months ${ }^{[39]}$. Another single center study was conducted in which a EuroQol (EQ-5D-5L) quality of life questionnaire and a Wexner fecal incontinence scale was given to 132 patients who underwent TEM for a variety of rectal lesions including adenocarcinoma with a median follow-up period of 96 months ${ }^{[40]}$. Those considered to have minor to no fecal incontinence were rated as having a Wexner score of 2 or less. Those considered to have non-minor incontinence were rated as having a Wexner score of 3 or more. Thirty eight patients (28.8\%) had higher Wexner scores of 3 or more and worse quality of life. The study concluded that TEM has significant rate of fecal incontinence that impairs quality of life. In comparison to laparoscopic low anterior resections which have reported Wexner scores of $5.2 \pm 4.2$ at 6 months postoperatively, and scores of $3.7 \pm 3.4$ at 12 months, the Wexner scores were similar for $\mathrm{TEM}^{[40]}$. TEM, however, still results in much lower fecal incontinence than open surgery which has reported Wexner scores as high as 14.2 at 6 months and 10.3 at 12 months after surgery ${ }^{[36]}$.

Another single center study followed 102 patients after TEM, including benign and malignant lesions, from 2009 to $2012^{[41]}$. Questionnaires including the European quality of life 5 dimensions questionnaire (EQ- 
Table 2. Robotic surgery for rectal cancer

\begin{tabular}{|c|c|c|c|c|c|c|c|c|}
\hline Ref. & Study type & Randomization & $\begin{array}{c}\text { Group } \\
\text { studied }\end{array}$ & $\begin{array}{c}\text { Sample } \\
\text { size }\end{array}$ & Follow up & Questionnaires & Main findings & $\begin{array}{l}\text { Level of } \\
\text { evidence }\end{array}$ \\
\hline $\begin{array}{l}\text { D'Annibale et } a{ }^{\left[{ }^{[29]}\right.}{ }^{\prime} \\
2013\end{array}$ & $\begin{array}{l}\text { Retrospective } \\
\text { single } \\
\text { center }\end{array}$ & No & $\begin{array}{l}\text { Robot } \\
\text { vs. Lap } \\
\text { TME }\end{array}$ & $\begin{array}{l}60 \text { men } \\
\text { (30 } \\
\text { Robot, } \\
30 \text { Lap) }\end{array}$ & 12 months & IPSS, IIEF & $\begin{array}{l}\text {-Both robot and lap had } \\
\text { decreased urinary func- } \\
\text { tion at } 1 \text { month and was } \\
\text { restored by } 12 \text { months } \\
\text {-Robot had better sexual } \\
\text { function at } 12 \text { months } \\
\text { compared to lap }\end{array}$ & 3 \\
\hline Kim et al. ${ }^{[30]}, 2012$ & $\begin{array}{l}\text { Prospective } \\
\text { single } \\
\text { center }\end{array}$ & No & $\begin{array}{l}\text { Robot } \\
\text { vs. Lap } \\
\text { TME }\end{array}$ & $\begin{array}{l}69 \text { (30 } \\
\text { Robot, } \\
39 \text { Lap) }\end{array}$ & 12 months & IPSS, IIEF & $\begin{array}{l}\text {-Robot recovered urinary } \\
\text { function at } 3 \text { months com- } \\
\text { pared to } 6 \text { months in lap } \\
\text {-Robot recovered sexual } \\
\text { function at } 6 \text { months com- } \\
\text { pared to } 12 \text { months in lap }\end{array}$ & $2 b$ \\
\hline Park et al. ${ }^{[31]}, 2013$ & $\begin{array}{l}\text { Retrospective } \\
\text { single } \\
\text { center }\end{array}$ & No & $\begin{array}{l}\text { Robot } \\
\text { vs. Lap } \\
\text { TME } \\
\text { (with } \\
\text { ISR) }\end{array}$ & $\begin{array}{l}29 \text { men } \\
(14 \\
\text { Robot, } 15 \\
\text { Lap) }\end{array}$ & 6 months & Wexner, IPSS, IIEF & $\begin{array}{l}\text {-Robot had better sexual } \\
\text { function at } 6 \text { months com- } \\
\text { pared to lap } \\
\text {-No difference in fecal } \\
\text { incontinence and urinary } \\
\text { function }\end{array}$ & 3 \\
\hline Park et al. ${ }^{[32]}, 2014$ & $\begin{array}{l}\text { Retrospective } \\
\text { single } \\
\text { center (case } \\
\text { matched) }\end{array}$ & No & $\begin{array}{l}\text { Robot } \\
\text { vs. Lap } \\
\text { TME }\end{array}$ & $\begin{array}{l}64 \text { (32 } \\
\text { Robot, } \\
32 \text { Lap) }\end{array}$ & 12 months & IPSS, IIEF & $\begin{array}{l}\text {-Robot had better sexual } \\
\text { function at } 6 \text { months but } \\
\text { both equal at } 12 \text { months } \\
\text { compared to lap } \\
\text {-No difference in urinary } \\
\text { function }\end{array}$ & 3 \\
\hline $\begin{array}{l}\text { Kamali et al. }{ }^{[34]}, \\
2017\end{array}$ & $\begin{array}{l}\text { Prospective } \\
\text { single } \\
\text { center }\end{array}$ & No & $\begin{array}{l}\text { Robot } \\
\text { vs. Lap } \\
\text { TME }\end{array}$ & $\begin{array}{l}36(18 \\
\text { Robot, } 18 \\
\text { Lap) }\end{array}$ & 12 months & $\begin{array}{l}\text { EORTC QLQ- } \\
\text { CR30, QLQ-CR29 }\end{array}$ & $\begin{array}{l}\text {-No difference in global } \\
\text { health } \\
\text {-Robot had better social } \\
\text { function, insomnia scores, } \\
\text { pain scores compared to } \\
\text { lap } \\
\text {-Robot had better impo- } \\
\text { tence scores compared to } \\
\text { lap }\end{array}$ & $2 b$ \\
\hline Kim et al. ${ }^{[36]}, 2014$ & $\begin{array}{l}\text { Retrospective } \\
\text { single } \\
\text { center }\end{array}$ & No & $\begin{array}{l}\text { Robot } \\
\text { vs. Open } \\
\text { TME } \\
\text { with ISR }\end{array}$ & $\begin{array}{l}222 \text { (108 } \\
\text { Robot, } \\
114 \\
\text { Open) }\end{array}$ & 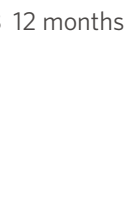 & FISI, Lawson, VAS & $\begin{array}{l}\text {-Robot had better fecal } \\
\text { incontinence scores com- } \\
\text { pared to open } \\
\text {-Robot had better sexual } \\
\text { function compared to } \\
\text { open }\end{array}$ & 3 \\
\hline Kim et al. ${ }^{[35]}, 2018$ & $\begin{array}{l}\text { Prospective } \\
\text { single } \\
\text { center }\end{array}$ & No & $\begin{array}{l}\text { Robotic } \\
\text { vs. Lap } \\
\text { TME }\end{array}$ & $\begin{array}{l}260 \text { (130 } \\
\text { Robot, } \\
130 \text { Lap) }\end{array}$ & 12 months & $\begin{array}{l}\text { EORTC QLQ-C30, } \\
\text { IPSS, IIEF }\end{array}$ & $\begin{array}{l}\text {-Robot had better emo- } \\
\text { tional and social function } \\
\text { compared to lap } \\
\text {-Robot had better symp- } \\
\text { toms of fatigue, insom- } \\
\text { nia, and financial issues } \\
\text { compared to lap } \\
\text {-Robot had better sexual } \\
\text { function compared to lap } \\
\text {-Robot had earlier return } \\
\text { of social function com- } \\
\text { pared to lap }\end{array}$ & $2 b$ \\
\hline $\begin{array}{l}\text { Jayne et }\left.a\right|^{[37]}, \\
2017\end{array}$ & $\begin{array}{l}\text { Prospective } \\
\text { multicenter }\end{array}$ & Yes & $\begin{array}{l}\text { Robot } \\
\text { vs. Lap } \\
\text { TME }\end{array}$ & $\begin{array}{l}471 \text { (237 } \\
\text { Rob, } 234 \\
\text { Lap) }\end{array}$ & 6 months & IPSS, IIEF, FSFI & $\begin{array}{l}\text {-No difference in overall } \\
\text { QOL at } 6 \text { months }\end{array}$ & 1 \\
\hline
\end{tabular}

Lap: laparoscopic; TME: total mesorectal excision; ISR: intersphincteric resection; QOL: quality of life; SF-36: short form general health survey of 36 questions, EORTC QLQ-C30: European organization for research and treatment of cancer quality of life questionnaire, 30 cancer non-specific questions; EORTC QLQ-CR38: European organization for research and treatment of cancer quality of life questionnaire, 38 colorectal cancer specific questions; IPSS: International Prostatic Symptom Score; IIEF: International Index of Erectile Function; FSFI: Female Sexual Function Index; ICIQ-MLUTS: International consultation on incontinence male lower urinary tract symptoms; ICIQ-FLUTS: International consultation on incontinence female lower urinary tract symptoms; FISI: Fecal Incontinence Severity Index; VAS: visual analogue scale; Wexner: Wexner Fecal Incontinence Score; Level of evidence: 1: randomized controlled trial; 2a: randomized prospective cohort study; 2 b: nonrandomized prospective cohort study; 3 : retrospective cohort study; 4 : case series

5D), EORTC QLQ-C30, and QLQ-CR29 were completed by patients pre-operatively and at 6, 12, 26, and 52 weeks after surgery. Quality of life diminished at 6 and 12 weeks after TEM compared to baseline $(P<0.05)$, 
but returned to baseline by 26 weeks. Anorectal function was worse at 6 weeks after surgery but returned to preoperative function at 12 weeks. Urinary function was not affected at any point after surgery. The study concluded that TEM has a transient and reversible impact on quality of life and anorectal function, without affecting urinary function ${ }^{[41]}$.

TEM has also been studied as a treatment after neoadjuvant chemotherapy and radiation. In a study comparison between 31 patients with T2 and T3 rectal cancer who underwent either TEM $v s$. laparoscopic TME after neoadjuvant therapy, the authors found that the TEM resulted in better body image $(P=0.006)$, defecation function $(P=0.01)$ and weight loss $(P=0.005)$ than the laparoscopic group ${ }^{[42]}$. At one month after surgery, the TEM group had better symptoms in terms of nausea, vomiting, appetite loss, and constipation compared to the laparoscopic group. At 6 months, the laparoscopic group had significantly worse global health status, emotional function, insomnia, and appetite loss, body image, and defecation problems. At one year, the TEM group showed better body image, defecation problems and weight loss compared to the laparoscopic group ${ }^{[42]}$.

A summary of studies examining quality of life after TEM for rectal cancer is found in Table 3.

\section{TAMIS}

TAMIS emerged recently as an alternative to TEM. A flexible transanal multichannel laparoscopic port is used that is shorter in length than the conventional TEM rectoscope. Advocates state the benefit of TAMIS as being easier to learn for surgeons who are already proficient in laparoscopy, and more readily available because no specialized insufflators are needed. Furthermore, the flexible TAMIS platform is lower in cost and requires less time to setup than TEM. Contrary to TEM which uses a long rectoscope and insufflation, the TAMIS technique depends entirely on adequate insufflation for maximal exposure due to the short length of the port. Similar to TEM, TAMIS does not include a TME, and therefore usually yields no nodal information. Existing data suggests that TAMIS and TEM both only be performed for rectal adenomas and low risk T1No rectal cancers, and patients who refuse proctectomy. If final pathology does reveal high risk features, positive margins, high tumor grade, then a salvage TME or adjuvant therapy may be needed.

In 2016, a short-term single-center study followed 24 patients with rectal adenomas and low risk T1 cancers with a median tumor height of $8 \mathrm{~cm}$ from the anal verge from 2011 to 2013 before TAMIS and 6 months afterwards $(2-17 \mathrm{~cm})^{[43]}$. In total, there were 20 adenomas and 4 low risk $\mathrm{T} 1$ cancers. Functional outcomes were assessed with the fecal incontinence severity index (FISI), and fecal incontinence quality of life (FIQL), and the generic EuroQol EQ-5D questionnaire. FISI and FIQL scores were unchanged from baseline at 6 months, and EQ-5D improved at 6 months ${ }^{[43]}$. García-Flórez et al ${ }^{[44]}$ followed 32 patients who underwent TAMIS over a 40 months period. These patients were not given quality of life questionnaires but questioned during clinic visit. Four weeks after surgery, 5 patients (15\%) complained of minor fecal incontinence to flatus or liquid stool. However, by eight weeks after surgery the incontinence resolved. No urinary or sexual dysfunction was affected. This study revealed that TAMIS resulted in good short-term and longterm functional outcomes comparable to $\mathrm{TEM}^{[44]}$.

Another study published in 2018 compared 37 patients who underwent a TAMIS between 2011 and 2014, and then compared their quality of life outcomes to 37 matched healthy controls to the same age, gender, and socio-economic status ${ }^{[45]}$. Questionnaires including the SF-36 and FISI questionnaire were given after a median follow-up duration of 36 months to patients with either adenomas or T1 carcinomas. They found that TAMIS resulted in impaired social function. This worsening was attributed possibly to the fecal incontinence that occurred in $70 \%$ of the patients who underwent TAMIS. The FISI score worsened from 8.3 points pre-operatively to 10.1 points 3 years after this study. TAMIS patients reported an overall similar quality of life in comparison to their counterparts. TAMIS patients scored a higher mental health and bodily pain 
Table 3. Transanal endoscopic microsurgery

\begin{tabular}{|c|c|c|c|c|c|c|c|c|}
\hline Ref. & Study type & Randomization & $\begin{array}{c}\text { Group } \\
\text { studied }\end{array}$ & $\begin{array}{l}\text { Sample } \\
\text { size }\end{array}$ & Follow up & Questionnaires & Main findings & $\begin{array}{l}\text { Level of } \\
\text { evidence }\end{array}$ \\
\hline Allaix et al. ${ }^{[39]}, 2011$ & $\begin{array}{l}\text { Prospective } \\
\text { single } \\
\text { center }\end{array}$ & No & TEM & 93 & 60 months & $\begin{array}{l}\text { Wexner, FIQL, } \\
\text { EORTC QLQ- } \\
\text { C30, QLQ-CR38, } \\
\text { EQ5D }\end{array}$ & $\begin{array}{l}\text {-TEM had mild fecal } \\
\text { incontinence postop } \\
\text { which returned to } \\
\text { baseline by } 60 \\
\text { months } \\
\text {-Study group had be- } \\
\text { nign and malignant } \\
\text { lesions }\end{array}$ & 4 \\
\hline $\begin{array}{l}\text { Jakubauskas et al. }{ }^{[40]} \text {, } \\
2018\end{array}$ & $\begin{array}{l}\text { Prospective } \\
\text { single } \\
\text { center }\end{array}$ & No & TEM & 132 & 96 months & Wexner, EQ5D & $\begin{array}{l}\text {-TEM had similar } \\
\text { fecal incontinence } \\
\text { scores compared to } \\
\text { historic lap scores, } \\
\text { but better than open } \\
\text { surgery } \\
\text {-Study group had be- } \\
\text { nign and malignant } \\
\text { lesions }\end{array}$ & 4 \\
\hline Hompes et al. ${ }^{[41]}, 2015$ & $\begin{array}{l}\text { Prospective } \\
\text { single } \\
\text { center }\end{array}$ & No & TEM & 102 & 12 months & $\begin{array}{l}\text { EORTC QLQ- } \\
\text { C30, QLQ-CR29, } \\
\text { EQ5D }\end{array}$ & $\begin{array}{l}\text {-TEM had mild fecal } \\
\text { incontinence postop } \\
\text { which returned to } \\
\text { baseline by } 26 \text { weeks } \\
\text {-TEM had overall } \\
\text { QOL effects which } \\
\text { were transient } \\
\text {-TEM had no effect } \\
\text { on urinary function } \\
\text {-Study group had be- } \\
\text { nign and malignant } \\
\text { lesions }\end{array}$ & 4 \\
\hline $\begin{array}{l}\text { D'Ambrosio et } a{ }^{\left[{ }^{[42]}\right.} \text {, } \\
2016\end{array}$ & $\begin{array}{l}\text { Prospective } \\
\text { single } \\
\text { center }\end{array}$ & No & $\begin{array}{l}\text { Neoad- } \\
\text { juvant } \\
\text { TEM vs. } \\
\text { Lap TME }\end{array}$ & $\begin{array}{l}31(15 \\
\text { TEM, } \\
16 \text { lap } \\
\text { TME) }\end{array}$ & 12 months & $\begin{array}{l}\text { EORTC QLQ-C30, } \\
\text { QLQ-CR38 }\end{array}$ & $\begin{array}{l}\text {-TEM had improved } \\
\text { overall QOL at 1, 6, } \\
12 \text { months than lap } \\
\text { TME }\end{array}$ & $2 b$ \\
\hline
\end{tabular}

TEM: transanal endoscopic microsurgery; Lap: laparoscopic; TME: total mesorectal excision; QOL: quality of life; EORTC QLQ-C30: European organization for research and treatment of cancer quality of life questionnaire, 30 cancer non-specific questions; EORTC QLQCR38: European organization for research and treatment of cancer quality of life questionnaire, 38 colorectal cancer specific questions; EORTC QLQ-CR29: European organization for research and treatment of cancer quality of life questionnaire, 29 colorectal cancer specific questions; FIQL: Fecal Incontinence Quality of Life Scale; EQ5D: European quality of life 5 dimensions questionnaire; Wexner: Wexner Fecal Incontinence Score; Level of evidence: 1: randomized controlled trial; 2a: randomized prospective cohort study; $2 \mathrm{~b}$ : nonrandomized prospective cohort study; 3 : retrospective cohort study; 4: case series

score compared to the control group. The authors described this as a "rejoice phenomenon" when the patient describes improved mental health after surgery with relief that a malignancy has been successfully excised. The study therefore concluded that TAMIS patients have similar quality of life compared to healthy controls, and social function is decreased which may or may not be related to fecal incontinence ${ }^{[45]}$.

A summary of studies examining quality of life after TAMIS for rectal cancer is found in Table 4.

\section{TaTME}

TaTME is an emerging technique for the treatment of mid and low rectal cancer referred to as a "bottomup" approach or transanal proctectomy described by Sylla et al ${ }^{[46]}$ in 2010 . Advocates attribute the benefits of the technique to decrease the "coning in" effect of conventional TMEs that may result in an incomplete distal mesorectal excision. Additionally, the technique is purported to allow for accurate identification of the distal resection margins, increased rate of sphincter preservation, and reduced sexual and urinary dysfunction. It is believed to be most beneficial for patients with narrow pelvises and excessive visceral fat. Others believe the technique results in lower conversion rates and reduced wound-related complications. However, major concerns about the technique include having a low tenuous anastomosis closer to the anal sphincter compared to laparoscopic or robotic TME, as well as anal sphincter damage caused by prolonged 
Table 4. Transanal minimally invasive surgery

\begin{tabular}{|c|c|c|c|c|c|c|c|c|}
\hline Ref. & Study type & Randomization & $\begin{array}{l}\text { Group } \\
\text { studied }\end{array}$ & $\begin{array}{l}\text { Sample } \\
\text { size }\end{array}$ & Follow up & Questionnaires & Main findings & $\begin{array}{l}\text { Level of } \\
\text { evidence }\end{array}$ \\
\hline $\begin{array}{l}\text { Verseveld et al. }{ }^{[43]}, \\
2016\end{array}$ & $\begin{array}{l}\text { Prospective } \\
\text { single } \\
\text { center }\end{array}$ & No & TAMIS & 24 & 6 months & FISI, FIQL, EQ5D & $\begin{array}{l}\text {-TAMIS had no } \\
\text { change in fecal incon- } \\
\text { tinence compared to } \\
\text { baseline } \\
\text {-TAMIS had better } \\
\text { overall QOL improved } \\
\text { compared to baseline } \\
\text {-Study group had } \\
\text { benign and malignant } \\
\text { lesions }\end{array}$ & 4 \\
\hline $\begin{array}{l}\text { García-Flórez et al. }{ }^{[44]} \text {, } \\
2017\end{array}$ & $\begin{array}{l}\text { Retrospective } \\
\text { single } \\
\text { center }\end{array}$ & No & TAMIS & 32 & $\begin{array}{l}40 \\
\text { months }\end{array}$ & $\begin{array}{l}\text { Questions at } \\
\text { clinic visit }\end{array}$ & $\begin{array}{l}\text {-TAMIS had fecal } \\
\text { incontinence postop } \\
\text { that resolved } \\
\text {-TAMIS had no } \\
\text { change in urinary or } \\
\text { sexual function } \\
\text {-Study group had } \\
\text { benign and malignant } \\
\text { lesions }\end{array}$ & 3 \\
\hline $\begin{array}{l}\text { Clermonts et al. }{ }^{[45]}, \\
2018\end{array}$ & $\begin{array}{l}\text { Prospective } \\
\text { single } \\
\text { center (Case } \\
\text { matched) }\end{array}$ & No & $\begin{array}{l}\text { TAMIS vs. } \\
\text { healthy } \\
\text { controls }\end{array}$ & $\begin{array}{l}37 \text { ( } 37 \\
\text { TAMIS, } \\
37 \text { healthy } \\
\text { controls) }\end{array}$ & 36 months & SF-36, FISI & $\begin{array}{l}\text {-TAMIS had similar } \\
\text { overall QOL compared } \\
\text { to healthy patients } \\
\text {-TAMIS had worse } \\
\text { social function } \\
\text { compared to healthy } \\
\text { patients } \\
\text {-TAMIS had better } \\
\text { bodily pain scores } \\
\text { compared to open } \\
\text {-Study group had } \\
\text { benign and malignant } \\
\text { lesions }\end{array}$ & 3 \\
\hline
\end{tabular}

TAMIS: transanal minimally invasive surgery; QOL: quality of life; SF-36: short form general health survey of 36 questions; EQ5D: european quality of life 5 dimensions questionnaire; FISI: Fecal Incontinence Severity Index; FIQL: Fecal Incontinence Quality of Life Scale; Level of evidence: 1: randomized controlled trial; 2a: randomized prospective cohort study; 2 b: nonrandomized prospective cohort study; 3 : retrospective cohort study; 4: case series

dilation of the anal canal. Furthermore, given the learning curve required for the technique, there may be increased risk of adjacent structures such as the pelvic floor muscles, prostatic urethra, and neurovasculature ${ }^{[47]}$. Most early single center short term studies described TaTME with similar outcomes in terms of operation time, blood loss, length of stay, and complication rates compared to laparoscopic $\mathrm{TME}^{[48]}$. Chang and $\mathrm{Kiu}^{[49]}$ performed a single center study in 2018 that found in comparing transanal TME $v$ s. laparoscopic surgery, that there were no significant differences in 30 day complication rate or pathologic outcomes. Atallah et al. ${ }^{[50]}$ described the results of a structured training program to teach TaTME, and found that surgeons early in their experience may have complications such as urethral injury $(5 / 20 ; 25 \%)$ and significant hemorrhage $(3 / 20,15 \%)$. Maykel described a comprehensive TaTME training program and described their experience with 40 patients and demonstrated the ability to achieve $100 \%$ complete mesorectal excision, acceptable leak rate of $6.5 \%$, low wound infection risk of $10 \%$, and a overall complication rate of $32.6 \%$ comprised of minor complications such as ileus $7.9 \%$, urinary retention $7.9 \%$, and urinary tract infections $5 \%{ }^{[51,52]}$. There were no urethral or ureter injuries in their group ${ }^{[51,52]}$.

In 2017, Koedam et al ${ }^{[53]}$ published a single center study examining the quality of life impact of TaTME in 30 rectal cancer patients who all underwent restorative coloanal anastomoses. Seventy-three percent of these patients underwent neoadjuvant therapy with either radiation only (40\%) or chemoradiation (33\%). These patients were evaluated prospectively, and given four questionnaires and found that the overall quality of life was significantly decreased at one month, but returned to near preoperative score at 6 months. This study found similar responses regarding the cancer-specific and colorectal cancer-specific 
questionnaires, in which scores dropped significantly one month after surgery, but were no longer significantly different at 6 months after surgery except for social function $(P=0.013)$ and anal pain $(P=0.013)$. Bladder function, male sexual function, and anorectal function after stoma closure was similarly significantly worse at one month postoperatively but not significantly different after 6 months ${ }^{[53]}$.

Another recent study examined 54 consecutive patients with rectal cancer (27 had TaTME vs. 27 had laparoscopic TME) and found that there were comparable functional and quality of life outcomes at 6 months. On the EORTC QLQ-CR29 questionnaire, more patients in the TaTME group reported more fecal incontinence $v s$. the laparoscopic TME group, but the overall low anterior resection syndrome (LARS) score was no different ${ }^{[54]}$.

Two ongoing multicenter trials will examine quality of life outcomes in patients who undergo transanal TME. The COLOR III trial will be an international multicenter superiority trial that will compare 1098 patients with mid or low rectal cancers scheduled for either transanal TME and conventional laparoscopic TME for the treatment of low rectal cancers ${ }^{[55]}$. Although the primary endpoint will be the circumferential resection margin, the secondary endpoints will include disease-free survival, overall survival, and quality of life. Serra-Aracil et al. ${ }^{[56]}$ published a protocol to study a combined TaTME combined with laparoscopy to evaluate if there would be a lower conversion rate than laparoscopic low anterior resection, and potentially improve patient recovery and overall morbidity, and quality of life measures. Quality of life measures will be examined preoperatively and 6 months after the closure of protective ileostomy using the EORTC QLQ-C30, QLQ-CR29, and LARS score.

A summary of studies examining quality of life after TaTME for rectal cancer is found in Table 5.

\section{DISCUSSION}

The ideal treatment objectives for rectal cancer include local and systemic disease control, overall survival and preservation of quality of life. Oncologic outcomes can be measured objectively, following rates of recurrence and mortality in follow up. On the other hand, questionnaires remain the mainstay of collecting data on quality of life in rectal cancer patients. These instruments are cost-efficient and practical, and tremendous amounts of data points can be collected in one setting. However, disadvantages of questionnaires include possible low completion rate, subjective nature of responses, issues interpreting the questions, lack of conscientious responses, and inability to probe responses. In addition, there may be a statistically significant numeric difference found on a quality of life instrument between two approaches, but may not be clinically relevant. Moreover, the term "quality of life" encompasses many facets of a patient's well-being and includes not only fecal incontinence, urinary incontinence, and sexual function, but also body image, pain, social connections and participation in activities of daily living. As a result, there are many types of questionnaires and not all studies utilize the same surveys. These factors make it challenging at times to compare quality of life data across studies. Large randomized studies should all utilize the most validated and updated scales available.

The results of our review suggest that minimally invasive surgeries for rectal cancer have tremendous potential in achieving equivalent outcomes to conventional open surgeries with the possible benefit of an improved quality of life. Most early studies of each of these MIS techniques were single institution and observational, focusing on safety and feasibility, and then cancer-specific outcomes. As experience grew, there was a transition to comparative studies, and then finally randomized control trials. Later studies examine quality of life as a relevant outcome. The most frequently used quality of life questionnaires were EORTC QLQ-C30, the colorectal module QLQ-CR38 and the SF-36, all validated instruments. Early single center studies of laparoscopic TME showed potential benefit in quality of life with an MIS approach ${ }^{[20-22]}$. 
Table 5. Transanal total mesorectal excision

\begin{tabular}{|c|c|c|c|c|c|c|c|c|}
\hline Ref. & Study type & Randomization & $\begin{array}{l}\text { Group } \\
\text { studied }\end{array}$ & $\begin{array}{l}\text { Sample } \\
\text { size }\end{array}$ & $\begin{array}{c}\text { Follow } \\
\text { up }\end{array}$ & Questionnaires & Main findings & $\begin{array}{l}\text { Level of } \\
\text { evidence }\end{array}$ \\
\hline Koedam et al. ${ }^{[53]}, 2017$ & $\begin{array}{l}\text { Prospective } \\
\text { single } \\
\text { center }\end{array}$ & No & TaTME & 30 & 6 months & $\begin{array}{l}\text { EORTC QLQ- } \\
\text { C30, QLQ-CR29, } \\
\text { EQ5D, LARS }\end{array}$ & $\begin{array}{l}\text {-TaTME had decreased } \\
\text { urinary function, sexual } \\
\text { function, fecal inconti- } \\
\text { nence and overall QOL } \\
\text { at } 1 \text { month compared to } \\
\text { baseline and returned } \\
\text { to normal by } 6 \text { months } \\
\text {-TaTME had decreased } \\
\text { social function and } \\
\text { anal pain at } 6 \text { months } \\
\text { compared to baseline } \\
\text {-TaTME had major } \\
\text { LARS in 33\% after } \\
\text { ileostomy closure }\end{array}$ & 4 \\
\hline $\begin{array}{l}\text { Veltcamp Helbach et al. }{ }^{[54]} \text {, } \\
2018\end{array}$ & $\begin{array}{l}\text { Prospec- } \\
\text { tive single } \\
\text { center }\end{array}$ & No & $\begin{array}{l}\text { TaTME vs. } \\
\text { Lap TME }\end{array}$ & 54 & 6 months & $\begin{array}{l}\text { EORTC QLQ- } \\
\text { C30, QLQ-CR29, } \\
\text { EQ5D, LARS, } \\
\text { IPSS }\end{array}$ & $\begin{array}{l}\text {-TaTME had similar } \\
\text { QOL compared to lap } \\
\text {-TaTME had worse fecal } \\
\text { incontinence compared } \\
\text { to lap (EORTC QLQ- } \\
\text { CR29 only) }\end{array}$ & $2 b$ \\
\hline $\begin{array}{l}\text { Deijen et al. }{ }^{[55]}, \\
2016 \text { (COLOR III) }\end{array}$ & $\begin{array}{l}\text { Prospective } \\
\text { multicenter }\end{array}$ & Yes $(2: 1)$ & $\begin{array}{l}\text { TaTME vs. } \\
\text { Lap TME }\end{array}$ & 1098 & $\begin{array}{l}60 \\
\text { months }\end{array}$ & $\begin{array}{l}\text { EORTC QLQ- } \\
\text { C30, QLQ-CR29, } \\
\text { EQ5D, LARS }\end{array}$ & -Pending & 1 \\
\hline $\begin{array}{l}\text { Serra-Aracil et al. }{ }^{[56]}, \\
2018\end{array}$ & $\begin{array}{l}\text { Prospective } \\
\text { multicenter }\end{array}$ & Yes (1:1) & $\begin{array}{l}\text { TaTME vs. } \\
\text { Lap TME }\end{array}$ & 116 & 6 months & $\begin{array}{l}\text { EORTC QLQ- } \\
\text { C30, QLQ-CR29, } \\
\text { LARS }\end{array}$ & -Pending & 1 \\
\hline
\end{tabular}

TaTME: transanal total mesorectal excision; Lap: laparoscopic; TME: total mesorectal excision; LARS: low anterior resection syndrome; QOL: quality of life; EORTC QLQ-C30: European organization for research and treatment of cancer quality of life questionnaire, 30 cancer non-specific questions; EORTC QLQ-CR29: European organization for research and treatment of cancer quality of life questionnaire, 29 colorectal cancer specific questions; EQ5D: European quality of life 5 dimensions questionnaire; IPSS: International Prostatic Symptom Score; Level of evidence: 1: randomized controlled trial; 2a: randomized prospective cohort study; 2b: nonrandomized prospective cohort study; 3: retrospective cohort study; 4: case series

However, in contrast, the recent multicenter randomized controlled trials have shown the results to be either equivalent or worse in the laparoscopic group ${ }^{[23-26]}$. It will be important to follow the final long term quality of life findings of the large randomized control trials of ACCOSOG Z6051 and ALaCaRT ${ }^{[27,28]}$. This may underscore the inherent problem of working in the fixed space of the bony pelvis with conventional laparoscopy. Restricted movements of working instruments, two-dimensional view, difficult ergonomics and an unstable platform can make laparoscopy for rectal cancer challenging and may lead to a high conversion rate or unsatisfactory dissection.

Key advances in robotic technology over the last two decades overcame challenges of laparoscopic and open surgery and allowed for enhanced three-dimensional view, and "wristed" instruments allowing for multiple degrees of freedom, a stable platform, and improved ergonomics. This was particularly important in complex colon and rectal surgery including procedures in the bony pelvis. For these reasons, robotic usage for all colorectal procedures grew from 2.6\% to 6.6\% between 2011-2015. In 2015, robotic utilization for rectopexy was $27 \%$, for low anterior resection was $13 \%$, and for abdominoperineal resection was $15 \%{ }^{[57]}$. Although the technology has been limited by decreased haptics, steep learning curve, and concern of increased cost, widespread utilization of robotics is spreading quickly. In terms of quality of life, robotic surgery may be more promising than laparoscopic surgery in its improvement in chronic pain and insomnia based on single center studies, showing an earlier return to baseline quality of life compared to laparoscopic surgery. Furthermore, several small single center short term studies demonstrated a significant improvement in sexual function. One study even showed a modest improvement in bladder function in robotic surgery patients compared to laparoscopic surgery patients ${ }^{[29-36]}$. Benefits have been attributed to the superior dissection allowed by robotic surgery. However, the multicenter ROLARR study showed that 
at 6 months there was no benefit in robotic surgery in terms of quality of life outcomes ${ }^{[37]}$. The three year results have yet to be reported. Like laparoscopic surgery though, robotic surgery may prove to have better outcomes in future trials once participating surgeons gain more expertise on their learning curve. The surgeons in the ROLARR trial had varying levels of experience: surgeons performing laparoscopy had an average of 91 previous laparoscopic cases while surgeons performing a robotic approach had an average of 50 previous robotic cases, possibly still in their learning curve. In addition, robotic systems are still in their infancy with newer robotic platforms and technology becoming more widely available.

TEM and TAMIS both allow for local resections that do improve quality of life compared to transabdominal surgeries that require rectal resections and increase need for diverting or permanent ostomies. These procedures require stretching of the anorectal ring, and patients should be counseled that may have some transient changes to their bowel function that can last several months. These modalities are mostly limited to treatment of early stage cancers. TEM and TAMIS may have a role for local excision after neoadjvuant therapy as well. This will need to be studied more closely with overall effect on quality of life in future randomized studies.

Transanal TME is the newest of MIS rectal cancer treatments and only small retrospective studies have described its effects on quality of life ${ }^{[53,54]}$. There has been some early concern for effect on incontinence and LARS scores possibility due to the low anastomosis. Morbidity including urethral injury warrants the need of continued studies as surgeons gain more experience. TaTME should be limited to surgeons who have taken the proper courses and have adequate mentoring. Studies comparing transanal TME to other approaches of rectal cancer treatment need to be conducted to better assess the potential benefit in cancerspecific outcomes and patients' overall wellbeing. Two future randomized studies may help clarify these questions $^{[55,56]}$.

In addition to the aforementioned MIS approaches, a new treatment strategy for rectal cancer has the potential to change quality of life after therapy for rectal cancer. This "watch-and-wait" strategy is for select patients who demonstrate a complete clinical response to total neoadjuvant therapy. These patients are observed closely and do not undergo any proctectomy or local excision if they show no evidence of recurrence in follow-up. This option is being extensively studied and can be used in multiple scenarios including after treatment for locally advanced (any $\mathrm{T} 3$, or $\mathrm{N}+$ ) and for lower risk tumors including $\mathrm{T} 2$ and high risk $\mathrm{T} 1$ lesions ${ }^{[58]}$. A small study of 29 near-complete responders who underwent TEM $v s .53$ complete responders to neoadjuvant chemotherapy who underwent no further surgery demonstrated a statistically significant improvement in quality of life and incontinence scores in those patients that had a complete response (and no TEM) at the end of a three year follow-up period $(2.3 v s .6 .5, P<0.001)^{[59]}$. In another study comparing 41 watch-and-wait patients to 41 patients who had neoadjuvant and surgery matched by gender, age, tumor stage, and tumor height, two year follow-up revealed better physical and cognitive function, body image, and overall global health status in the watch-and-wait group compared to the surgical group. Furthermore, the "watch-and-wait" patients had fewer problems with defecation, sexual and urinary tract function ${ }^{[0]}$. The quality of life problems that are noted in the "watch-and-wait" group can be partly attributed to the effects of radiation therapy alone and its known effects on fecal incontinence and genitourinary function. Still, "watch-and-wait" treatment may be a valid option for complete clinical responders in the future. More studies will need to be done evaluating the concordance of complete clinical response with a true pathologic complete response to limit future recurrence. "Watch-and-wait" has the potential to profoundly impact quality of life after therapy for rectal cancer.

Surgery for rectal cancer is difficult and continues to evolve. Completing a TME safely relies on multiple patient and surgeon factors. Any approach, including organ-preserving options and local excision, can be associated with significant changes in quality of life. Care must be taken to study innovative new treatment 
algorithms and technical advances with assessment of both oncologic and functional outcomes. An ideal trial looking at quality of life would be a large randomized controlled trial with adequate power, baseline and long term quality of life assessment with a high response rate using the most commonly-used and validated questionnaires.

\section{CONCLUSION}

MIS in the treatment of rectal cancer is ever evolving, with a continuous effort to achieve equivalent if not better oncologic outcomes with less surgical trauma and maintain, and possibly improve functional outcomes. Surgeons continue to use new tools and approaches to maximize patient benefit. Future studies should include surgeons with proficient experience in new minimally invasive robotic and transanal rectal cancer surgery, all in an effort to help patients live longer and live better.

\section{DECLARATIONS}

\section{Authors' contributions}

Conception and design of the work, acquisition, analysis, interpretation of data, drafting and revising the work: Chen JH, Bello BL

Conception and design of the work, revising the work: Ayscue JM, Bayasi M, Fitzgerald JF, Stahl TJ

\section{Availability of data and materials}

Not applicable.

\section{Financial support and sponsorship}

None.

\section{Conflicts of interest}

All authors declared that there are no conflicts of interest.

\section{Ethical approval and consent to participate}

Not applicable.

\section{Consent for publication}

Not applicable.

\section{Copyright}

(c) The Author(s) 2018.

\section{REFERENCES}

1. Colon Cancer Laparoscopic or Open Resection Study Group, Buunen M, Veldkamp R, Hop WC, Kuhry E, et al. Survival after laparoscopic surgery versus open surgery for colon cancer: long-term outcome of a randomised clinical trial. Lancet Oncol 2009; $10: 44-52$.

2. Salem JF, Gummadi S, Marks JH. Minimally invasive approaches to colon cancer. Surg Oncol Clin N Am 2018;27:303-18.

3. Deijen CL, Vasmel JE, de Lange-de Klerk ESM, Cuesta MA, Coene PLO, et al. Ten-year outcomes of a randomised trial of laparoscopic versus open surgery for colon cancer. Surg Endosc 2017;31:2607-15.

4. Jayne DG, Guillou PJ, Thorpe H, Quirke P, Copeland J, et al. Randomized trial of laparoscopic-assisted resection of colorectal carcinoma: 3-year results of the UK MRC CLASICC trial group. J Clin Oncol 2007;25:3061-8.

5. Guerrieri M, Campagnacci R, De Sanctis A, Lezoche G, Massucco P, et al. Laparoscopic versus open colectomy for TNM stage III colon cancer: results of a prospective multicenter study in Italy. Surg Today 2012;42:1071-7.

6. Kitano S, Inomata M, Mizusawa J, Katayama H, Watanabe M, et al. Survival outcomes following laparoscopic versus open D3 dissection for stage II or III colon cancer (JCOG0404): a phase 3, randomised controlled trial. Lancet Gastroenterol Hepatol 2017;2:261-8.

7. Camilleri-Brennan J, Steele RJ. Quality of life after treatment for rectal cancer. Br J Surg 1998;85:1036-43.

8. Brazier J, Roberts J, Deverill M. The estimation of a preference-based measure of health from the SF-36. J Health Econ 2002;21:271-92.

9. Mosconi P, Apolone G, Barni S, Secondino S, Sbanotto A, et al. Quality of life in breast and colon cancer long-term survivors: an 
assessment with the EORTC QLQ-C30 and SF-36 questionnaires. Tumori 2002;88:110-6.

10. Gujral S, Conroy T, Fleissner C, Sezer O, King PM, et al. Assessing quality of life in patients with colorectal cancer: an update of the EORTC quality of life questionnaire. Eur J Cancer 2007;43:1564-73.

11. Uwer L, Rotonda C, Guillemin F, Miny J, Kaminsky MC, et al. Responsiveness of EORTC QLQ-C30, QLQ-CR38 and FACT-C quality of life questionnaires in patients with colorectal cancer. Health Qual Life Outcomes 2011;9:70.

12. Sprangers MA, te Velde A, Aaronson NK. The construction and testing of the EORTC colorectal cancer-specific quality of life questionnaire module (QLQ-CR38). European Organization for Research and Treatment of Cancer Study Group on Quality of Life. Eur J Cancer 1999;35:238-47.

13. Batista-Miranda JE, Regalado Pareja R, Huguet Pérez J, Montlleo Sánchez M, Araño Bertran P. The use of the IPSS questionnaire in surgical patients. International Prostatic Symptom Score. Actas Urol Esp 1995;19:227-33. (in Spanish)

14. Rosen RC, Riley A, Wagner G, Osterloh IH, Kirkpatrick J, et al. The international index of erectile function (IIEF): a multidimensional scale for assessment of erectile dysfunction. Urology 1997;49:822-30.

15. de Silva G, Furukan R, Goonewardene M. Validation of the Sinhala translation of the international consultation on incontinence modular questionnaire for female lower urinary tract symptoms among women in Sri Lanka. Int Urogynecol J 2017;28:1895-9.

16. Pourmomeny AA, Ghanei B, Alizadeh AF. Reliability and validity of the persian language version of the international consultation on incontinence questionnaire - male lower urinary tract symptoms (ICIQ-MLUTS). Low Urin Tract Symptoms 2018;10:190-2.

17. Vroege JA. The sexual health inventory for men (IIEF-5). Int J Impot Res 1999;11:177.

18. Rosen R, Brown C, Heiman J, Leiblum S, Meston C, et al. The Female Sexual Function Index (FSFI): a multidimensional self-report instrument for the assessment of female sexual function. J Sex Marital Ther 2000;26:191-208.

19. Moghadamyeghaneh Z, Carmichael JC, Mills S, Pigazzi A, Nguyen NT, et al. Variations in laparoscopic colectomy utilization in the United States. Dis Colon Rectum 2015;58:950-6.

20. Breukink SO, van der Zaag-Loonen HJ, Bouma EM, Pierie JP, Hoff C, et al. Prospective evaluation of quality of life and sexual functioning after laparoscopic total mesorectal excision. Dis Colon Rectum 2007;50:147-55.

21. Braga M, Frasson M, Vignali A, Zuliani W, Capretti G, et al. Laparoscopic resection in rectal cancer patients: outcome and cost-benefit analysis. Dis Colon Rectum 2007;50:464-71.

22. George D, Pramil K, Kamalesh NP, Ponnambatheyil S, Kurumboor P. Sexual and urinary dysfunction following laparoscopic total mesorectal excision in male patients: a prospective study. J Minim Access Surg 2018;14:111-7.

23. Guillou PJ, Quirke P, Thorpe H, Walker J, Jayne DG, et al. Short-term endpoints of conventional versus laparoscopic-assisted surgery in patients with colorectal cancer (MRC CLASICC trial): multicentre, randomised controlled trial. Lancet 2005;365:1718-26.

24. Jeong SY, Park JW, Nam BH, Kim S, Kang SB, et al. Open versus laparoscopic surgery for mid-rectal or low-rectal cancer after neoadjuvant chemoradiotherapy (COREAN trial): survival outcomes of an open-label, non-inferiority, randomised controlled trial. Lancet Oncol 2014;15:767-74.

25. Bonjer HJ, Deijen CL, Abis GA, Cuesta MA, van der Pas MH, et al. A randomized trial of laparoscopic versus open surgery for rectal cancer. N Engl J Med 2015;372:1324-32.

26. Andersson J, Abis G, Gellerstedt M, Angenete E, Angerås U, et al. Patient-reported genitourinary dysfunction after laparoscopic and open rectal cancer surgery in a randomized trial (COLOR II). Br J Surg 2014;101:1272-9.

27. Fleshman J, Branda M, Sargent DJ, Boller AM, George V, et al. Effect of laparoscopic-assisted resection vs open resection of stage II or III rectal cancer on pathologic outcomes: the ACOSOG Z6051 randomized clinical trial. JAMA 2015;314:1346-55.

28. Stevenson AR, Solomon MJ, Lumley JW, Hewett P, Clouston AD, et al. Effect of laparoscopic-assisted resection vs open resection on pathological outcomes in rectal cancer: the ALaCaRT randomized clinical trial. JAMA 2015; 314:1356-63.

29. D'Annibale A, Pernazza G, Monsellato I, Pende V, Lucandri G, et al. Total mesorectal excision: a comparison of oncological and functional outcomes between robotic and laparoscopic surgery for rectal cancer. Surg Endosc 2013;27:1887-95.

30. Kim JY, Kim NK, Lee KY, Hur H, Min BS, et al. A comparative study of voiding and sexual function after total mesorectal excision with autonomic nerve preservation for rectal cancer: laparoscopic versus robotic surgery. Ann Surg Oncol 2012;19:2485-93.

31. Park SY, Choi GS, Park JS, Kim HJ, Ryuk JP. Short-term clinical outcome of robot-assisted intersphincteric resection for low rectal cancer: a retrospective comparison with conventional laparoscopy. Surg Endosc 2013;27:48-55.

32. Park SY, Choi GS, Park JS, Kim HJ, Ryuk JP, et al. Urinary and erectile function in men after total mesorectal excision by laparoscopic or robot-assisted methods for the treatment of rectal cancer: a case-matched comparison. World J Surg 2014;38:1834-42.

33. Broholm M, Pommergaard HC, Gögenür I. Possible benefits of robot-assisted rectal cancer surgery regarding urological and sexual dysfunction: a systematic review and meta-analysis. Colorectal Dis 2015;17:375-81.

34. Kamali D, Omar K, Imam SZ, Jha A, Reddy A, et al. Patient quality of life and short-term surgical outcomes between robotic and laparoscopic anterior resection for adenocarcinoma of the rectum. Tech Coloproctol 2017;21:355-61.

35. Kim HJ, Choi GS, Park JS, Park SY, Yang CS, et al. The impact of robotic surgery on quality of life, urinary and sexual function following total mesorectal excision for rectal cancer: a propensity score-matched analysis with laparoscopic surgery. Colorectal Dis 2018;20:O103-13

36. Kim JC, Lim SB, Yoon YS, Park IJ, Kim CW, et al. Completely abdominal intersphincteric resection for lower rectal cancer: feasibility and comparison of robot-assisted and open surgery. Surg Endosc 2014;28:2734-44.

37. Jayne D, Pigazzi A, Marshall H, Croft J, Corrigan N, et al. Effect of robotic-assisted vs conventional laparoscopic surgery on risk of conversion to open laparotomy among patients undergoing resection for rectal cancer: the ROLARR randomized clinical trial. JAMA 2017;318:1569-80.

38. Clancy C, Burke JP, Albert MR, O'Connell PR, Winter DC. Transanal endoscopic microsurgery versus standard transanal excision for the removal of rectal neoplasms: a systematic review and meta-analysis. Dis Colon Rectum 2015;58:254-61. 
39. Allaix ME, Rebecchi F, Giaccone C, Mistrangelo M, Morino M. Long-term functional results and quality of life after transanal endoscopic microsurgery. Br J Surg 2011;98:1635-43.

40. Jakubauskas M, Jotautas V, Poskus E, Mikalauskas S, Valeikaite-Tauginiene G, et al. Fecal incontinence after transanal endoscopic microsurgery. Int J Colorectal Dis 2018;33:467-72.

41. Hompes R, Ashraf SQ, Gosselink MP, van Dongen KW, Mortensen NJ, et al. Evaluation of quality of life and function at 1 year after transanal endoscopic microsurgery. Colorectal Dis 2015;17:O54-61.

42. D'Ambrosio G, Paganini AM, Balla A, Quaresima S, Ursi P, et al. Quality of life in non-early rectal cancer treated by neoadjuvant radiochemotherapy and endoluminal loco-regional resection (ELRR) by transanal endoscopic microsurgery (TEM) versus laparoscopic total mesorectal excision. Surg Endosc 2016;30:504-11.

43. Verseveld M, Barendse RM, Gosselink MP, Verhoef C, de Graaf EJ, et al. Transanal minimally invasive surgery: impact on quality of life and functional outcome. Surg Endosc 2016;30:1184-7.

44. García-Flórez LJ, Otero-Díez JL, Encinas-Muñiz AI, Sánchez-Domínguez L. Indications and outcomes from 32 consecutive patients for the treatment of rectal lesions by transanal minimally invasive surgery. Surg Innov 2017;24:336-42.

45. Clermonts SHEM, van Loon YT, Wasowicz DK, Langenhoff BS, Zimmerman DDE. Comparative quality of life in patients following transanal minimally invasive surgery and healthy control subjects. J Gastrointest Surg 2018;22:1089-97.

46. Sylla P, Rattner DW, Delgado S, Lacy AM. NOTES transanal rectal cancer resection using transanal endoscopic microsurgery and laparoscopic assistance. Surg Endosc 2010;24:1205-10.

47. Lee GC, Sylla P. Shifting paradigms in minimally invasive surgery: applications of transanal natural orifice transluminal endoscopic surgery in colorectal surgery. Clin Colon Rectal Surg 2015;28:181-93.

48. Rasulov AO, Mamedli ZZ, Gordeyev SS, Kozlov NA, Dzhumabaev HE. Short-term outcomes after transanal and laparoscopic total mesorectal excision for rectal cancer. Tech Coloproctol 2016;20:227-34.

49. Chang TC, Kiu KT. Kiu. Transanal total mesorectal excision in lower rectal cancer: comparison of short-term outcomes with conventional laparoscopic total mesorectal excision. J Laparoendosc Adv Surg Tech A 2018;28:365-9.

50. Atallah SB, DuBose AC, Burke JP, Nassif G, deBeche-Adams T, et al. Uptake of transanal total mesorectal excision in North America: initial assessment of a structured training program and the experience of delegate surgeons. Dis Colon Rectum 2017;60:1023-31.

51. Maykel JA. Comprehensive training and safe implementation of a transanal total mesorectal excision program. Dis Colon Rectum 2017;60:995-6.

52. Maykel JA, Phatak UR, Suwanabol PA, Schlussel AT, Davids JS, et al. Initiation of a transanal total mesorectal excision program at an academic training program: evaluating patient safety and quality outcomes. Dis Colon Rectum 2017;60:1267-72.

53. Koedam TW, van Ramshorst GH, Deijen CL, Elfrink AK, Meijerink WJ, et al. Transanal total mesorectal excision (TaTME) for rectal cancer: effects on patient-reported quality of life and functional outcome. Tech Coloproctol 2017;21:25-33.

54. Veltcamp Helbach M, Koedam TWA, Knol JJ, Velthuis S, Bonjer HJ, et al. Quality of life after rectal cancer surgery: differences between laparoscopic and transanal total mesorectal excision. Surg Endosc 2018; doi: 10.1007/s00464-018-6276-Z.

55. Deijen CL, Velthuis S, Tsai A, Mavroveli S, de Lange-de Klerk ES, et al. COLOR III: a multicentre randomised clinical trial comparing transanal TME versus laparoscopic TME for mid and low rectal cancer. Surg Endosc 2016;30:3210-5.

56. Serra-Aracil X, Zárate A, Mora L, Serra-Pla S, Pallisera A, et al. Study protocol for a multicenter prospective controlled and randomized trial of transanal total mesorectal excision versus laparoscopic low anterior resection in rectal cancer. Int J Colorectal Dis 2018;33:64955.

57. Damle A, Damle RN, Flahive JM, Schlussel AT, Davids JS, et al. Diffusion of technology: trends in robotic-assisted colorectal surgery. Am J Surg 2017;214:820-4.

58. Smith JJ, Chow OS, Gollub MJ, Nash GM, Temple LK, et al. Organ preservation in rectal adenocarcinoma: a phase II randomized controlled trial evaluating 3-year disease-free survival in patients with locally advanced rectal cancer treated with chemoradiation plus induction or consolidation chemotherapy, and total mesorectal excision or nonoperative management. BMC Cancer 2015;15:767.

59. Habr-Gama A, Lynn PB, Jorge JM, São Julião GP, Proscurshim I, et al. Impact of organ-preserving strategies on anorectal function in patients with distal rectal cancer following neoadjuvant chemoradiation. Dis Colon Rectum 2016;59:264-9.

60. Hupkens BJP, Martens MH, Stoot JH, Berbee M, Melenhorst J, et al. Quality of life in rectal cancer patients after chemoradiation: watch-and-wait policy versus standard resection - a matched-controlled study. Dis Colon Rectum 2017;60:1032-40. 